\title{
СТАНОВЛЕННЯ ПОЛІТОЛОГІЇ В ДЕЯКИХ КРАЇНАХ ЦЕНТРАЛЬНО-СХІДНОЇ ЄВРОПИ ЗА КОМУНІСТИЧНИХ РЕЖИМІВ
}

\author{
О. I. Романюк
}

Романюк О. I. Становлення політології в деяких країнах Центрально-Східної Європи за комуністичних режимів. Статтю присвячено з'ясуванню особливостей становлення політології як навчальної та наукової дисципліни в Югославії, Польщі та Угорщині під час функціонування комуністичних режимів. Становлення політології в цих країнах автор пов'язує зі спробою їх керівництва відійти від сталінської моделі соціалізму. Хоча східноєвропейська політологія являла еклектичну суміш марксистської теорії політики з західною політичною наукою, проте в подальшому вона сприяла посткомуністичним трансформаціям.

Ключові слова: політологія; науковий соціалізм; комуністичні режими; тоталітаризм; Югославія; Польща; Угорщина.

Романюк А. И. Становление политологии в некоторых странах Центрально-Восточной Европы в условиях коммунистических режимов. Статья посвящена выяснению особенностей становления политологии как научной и учебной дисциплины в Югославии, Польше и Венгрии в период функционирования коммунистических режимов. Становление политогии в этих странах автор связывает с попыткой их руководства отойти от сталинской модели социализма. Хотя восточноевропейская политология представляла эклектическую смесь марксистской теории политики с западной политической наукой, однако в дальнейшем она способствовала посткомунистическим трансформациям.

Ключевые слова: политология; научный социализм; коммунистические режимы; тоталитаризм; Югославия; Польша; Венгрия.

Romanyuk O. I. A becoming of political science in some countries of East Central Europe during of the communist regime. This article is devoted to clarify the features of becoming of the political science as an academic discipline in Yugoslavia, Poland and Hungary during of the communist regimes. The author connects the becoming of political science in these countries with an attempt of its leadership to move away from the Stalinist model of socialism. Although the Eastern political science represented an eclectic mixture of Marxist political theory with Western political science, but it has contributed to the postcommunist transformations in the future.

Keyworlds: political science; scientific socialism; communist regimes; totalitarianism; Yugoslavia; Poland; Hungary.

Політологія (Political Science) як навчальна та самостійна наукова дисципліна виникла в другій половині XIX ст. у США з об'єктивної необхідності в реінтеграції американського суспільства після громадянської війни 1861-1865 pp¹. Але до середини ХХ ст. вона залишалися переважно американською наукою. Світове поширення політологія одержала після Другої світової війни, що унаочнила яку загрозу людству несуть у собі антидемократичні режими. 3 метою виховання демократичної свідомості молодої генерації в 1948 р. ЮНЕСКО рекомендувала всім країнам-членам ООН впровадити в навчальний процес курс політичної науки. Країни Західної Європи відразу ж сприйняли цю рекомендацію, що спричинило фундацію в західноєвропейських університетах політологічних кафедр та факультетів. У країнах третього світу становлення політології відбувалося з переходом їх до демократії.

Проте після Другої світової війни світ був розколений на дві системи, що в комуністичному дискурсі рефлектувалися як системи капіталізму та соціалізму, у західному - як вільний та комуністичний світи. За своєю сутністю комуністичний світ являв собою низку тоталітарних держав під проводом Радянського Союзу, в яких монополія комуністичної партії на владу та монополія партійної держави на засоби суспільного виробництва доповнювалися монополією марксистсько-ленінської ідеології, що намагалася підкорити собі 
всю суспільну культуру, включаючи науку та освітуㄹ․ У комуністичних державах проблеми політичного розвитку студіювалися в межах наукового комунізму - соціально-політичній теорії марксизму, яка виступала методологічним підгрунтям усіх суспільних наук. Основними постулатами наукового комунізму були: класова боротьба як рушійна сила історичного розвитку; неминучість загибелі капіталізму та комуністичного майбутнього всього людства; комуністична партійність як принцип підходу до оцінки суспільно-політичних явищ; непримиренна боротьба проти буржуазної ідеології та політики.

Ставити під сумнів основні постулати наукового комунізму в комуністичних країнах було заборонено. У практичній царині науковому комунізмові були притаманні апологетика (наукоподібне обгрунтування правильності політики партійно-державного керівництва) та конфронтація з немарксистською політологією Заходу. 3 метою формування «правильного світогляду» молодої генерації науковий комунізм у 1963 р. став нормативною (обов'язковою) навчальною дисципліною у вишах СРСР, а потім і в інших комуністичних країнах ${ }^{3}$, окрім Югославії та Польщі. У цих країнах за комуністичних режимів замість наукового комунізму було інституалізовано як наукову та навчальну дисципліну політологію. Наприкінці комуністичного часу цей процес поширився й на Угорщину.

Становлення політології в комуністичних країнах висвітлювалося в працях Йована Джорджевича ${ }^{4}$, Томіслава Янтола ${ }^{5}$, Міряни Касапович ${ }^{6}$, Чеслава Мойсевича ${ }^{7}$, Кароля Яновського ${ }^{8}$, Дьордя Сабослаї ${ }^{9}$, Мате Сабо ${ }^{10}$, проте вони стосуються окремих держав. Спроба узагальнити процес становлення політичної науки в комуністичних країнах зроблена у статті американських політологів Девіда Павелла і Пола Шоупа ${ }^{11}$, але вона була опублікована ще в 1970 році й тому не відбиває багато аспектів цього процесу. Узагальнюючих праць 3 проблеми становлення політології за комуністичних режимів, що охоплювали би весь період їх функціонування аж до загибелі, немає. Мета даної статті полягає в осмисленні причин і особливостей фундації політології в колишніх комуністичних країнах та впливу цього наукового та освітнього напряму на процес поступової детоталітаризації суспільства.

\section{Югославія: від ревізії сталінського соціалізму та партійної просвіти до політичної науки}

Першою країною, в якій за комуністичного режиму було інституалізовано політологію, була Югославія. У 1945-1947 рр. за основу суспільно-політичної системи там була прийнята радянська модель. Конфлікт між радянським та югославським керівництвами, що виник в 1948 р. внаслідок того, що керівництво Югославії відмовилося підкоритися Сталіну стосовно утворенню Балканської Федерації, призвів до розриву міждержавних і міжпартійних відносин між СССР і ФНРЮ та до остракізму КПЮ в міжнародному комуністичному русі. Почалася пропагандистська кампанія, спрямована на дискредитацію югославського керівництва. Стверджувалося, що в Югославії існує «антикомуністичний поліцейський режим фашистського типу», за якого владу захопила «кривава кліка ТітоРанковича». Югославське керівництво відповіло на це звинуваченням сталінського керівництва в переродженні соціалізму в державно-капіталістичну систему, догматичній ревізії марксизму-ленінізму, бюрократизації партії та країни та почало пошуки альтернативної моделі соціалізму.

На початку 1950-х рр. Компартія Югославії висуває концепцію самоврядного соціалізму, яка стала теоретичною основою югославської політології. У підгрунтя цієї концепції було покладено тезу Маркса, що комунізм - це система «асоиіації вільних і рівних виробників»> ${ }^{12}$ та розуміння соціалізму як перехідного періоду від капіталізму до комунізму. Відповідно до цього головним завданням соціалізму проголошувався розвиток самоврядування трудящих (передусім виробничого), що здійснюється під керівництвом компартії, але 3 розвитком соціалістичного самоврядування роль партії має послаблюватися. На практиці цю концепцію було втілено у децентралізації економіки; передачі керівництва підприємствами (що залишилися в державній власності) трудовим колективам; створенням на підприємствах робітничих рад, які разом з адміністрацією стали визначати стратегію їх діяльності та розпоряджатися заробленими коштами; скасуванні обов'язкових поставок продукції для сільгосппідприємств; наданні можливості залишати селянам кооперативи 
та створювати приватні господарства; децентралізації органів влади; розширенні прав республік; впровадженні обмеженого місцевого самоврядування; зміні форм та методів діяльності партії ${ }^{13}$.

Розбудова самоврядного соціалізму вимагала наукових рекомендацій стосовно реформування політичних відносин. 3 метою координації наукових досліджень в галузі політики, в грудні 1954 р. було створено Югославську асоціацію політичної науки ${ }^{14}$. За самоврядного соціалізму партійні органи втрачали функцію керівництва економікою та мали зосередитися на політичній роботі, що зумовило становлення в Югославії політології не тільки як наукового, але й навчального напряму.

На початку 1960-х років на базі шкіл вдосконалення партійних кадрів у Белграді (1960), Любляні (1961) та Сараєво (1961) були створені вищі школи політичної науки, випускникам яких по закінченні навчання стали надаватися дипломи про вищу освіту 3 кваліфікацією «політолог». Спочатку ці школи готували кадри партійних працівників, але 3 часом вони були перетворені на відкриті навчальні заклади. У 1968 р. вища школи політичної науки в Белграді включається до складу Белградського університету, перетворюючись на факультет політичної науки. У 1970 р на базі вищих шкіл політичної науки виникають факультет політичної науки в університеті Сараєво та факультет соціології, політичної науки та журналістики в університеті Любляни. Але першим загальноосвітнім політологічним закладом в соціалістичній Югославії став факультет політичної науки у Загребському університеті, утворений рішенням хорватського парламенту 1962 p. ${ }^{15}$. Його виникнення сталося внаслідок реорганізації Вищої школи журналістики, що була заснована в Загребі 1949 р. для підготовки кадрів партійних пропагандистів. Політологічні факультети стали готувати фахівців з політичної освіти та наукових досліджень в галузі політики, міжнародних відносин, журналістики, соціальних комунікацій та соціальної роботи. Проте вони продовжували готувати й партійні кадри, з лав яких вийшло багато політичних діячів.

У межах політологічних факультетів виникли аспірантури, докторантури та спеціалізовані ради з захисту дисертацій з політичної проблематики. Основними завданнями югославської політології як наукового напряму стали розробка наукових рекомендацій стосовно реорганізації влади в умовах соціалістичного самоврядування народу, пошук оптимальної моделі розв'язання національного питання в межах багатонаціональної соціалістичної держави та протистояння радянській пропаганді, яка не тільки за часів Сталіна, але й пізніше негативно ставилася до «югославського експерименту». Проте, внаслідок комуністичного характеру політичного режиму, югославська політологія рефлектувала себе як «марксистська політична наука», що мала антибуржуазну та антизахідну спрямованість ${ }^{16}$.

\section{Становлення науки про політику в Польщі}

У Польщі після Другої світової війни був встановлений просталінський режим Болеслава Берута, який копіював радянську модель соціалізму. Смерть Берута, що сталася в Москві 12 березня 1956 р., та антикомуністичні протести у Познані в червні цього ж року, зумовили зміни в суспільно-політичному житті країни. У жовтні 1956 р. VIII пленум ЦК ПОРП обрав першим секретарем ЦК ПОРП Владислава Гомулку, який в 1951-1954 pр. був ув'язнений за звинуваченнями в «правонаціоналістичному ухилі». Прийшовши до влади, Гомулка почав процес десталінізаціії країни та став реалізувати ідею «польського шляху до соціалізму». Було припинено колективізацію сільського господарства; селянам надано право виходити з кооперативів, внаслідок чого вони розвалилися. Легалізовано дрібнотоварне виробництва на грунті індивідуальної власності. На державних підприємствах створювалися органи робітничого самоврядування. Нормалізовані стосунки 3 католицькою церквою. Пом'якшено цензуру засобів масової інформації.

Ідея польського шляху до соціалізму потребувала концептуального обгрунтування, внаслідок чого 1957 р. в Польщі створюється Польське товариство політичних наук (Polske Towarzystwo Nauk Politychnych - PTNP), функція якого полягала в координації наукових досліджень у галузі політики. На початку воно являло собою об'єднання наукових осередків, що займалися політичною проблематикою. У 1960 р. відбулася реорганізація 
PTNP, внаслідок чого воно перетворюється на громадську організацію, а колективне членство в ньому змінюється на індивідуальне ${ }^{17}$. PTNP відіграла велику роль у налаштуванні політичних досліджень на розв'язання практичних проблем розвитку суспільства, залучення до їх методологічної бази західних теорій та концепцій, поширенню політичних знань, розбудові політологічних структур. 31965 р. РТNP починає видавати науковий часопис «Студія політичних наук» (Studia Nauk Politycznych). До 1965 р. осередок PTNP діяв лише в Варшавському університеті і нараховував 120 членів. У 1985 р. відділення PTNP, в яких діяло 550 науковців, функціонували вже в чотирнадцяти університетських містах ${ }^{18}$.

Одним із заходів $з$ десталінізаціії Польщі було усунення з викладання в вищій школі предмету «Основи марксизму-ленінізму» (Podstawy marksizmu-leninizmu) ${ }^{19}$, що грунтувався на «звульгаризованій - ленінсько-сталінській - інтерпретації марксизму» ${ }^{20}$. Проте відчувши брак світоглядних основ у молодої генерації, XIII пленум ЦК ПОРП (липень 1963 р.) ухвалив рішення про включення до програми навчання студентів академічної дисципліни «Основи політичних наук» («Podstawy nauk politycznych»), яка стала викладатися в польських вишах 3 1963/1964 навчального року ${ }^{21}$. Після студентських заворушень, що сталися в ПНР в березні 1968 р., ця дисципліна стає обов'язковою для всіх студентів і починає викладатися на третьому курсі навчання. Відповідно в польських вишах почалося створення політологічних кафедр, а в університетах - факультетів та інститутів політичних наук. Були введені наукові ступені в галузі політичних наук, виникли спеціалізовані ради із захисту дисертацій. Перша докторська дисертація 3 цього напряму суспільствознавства була захищена в Інституті політичних наук Варшавського університету в 1971 р.22. У 1972 р. у межах Польської академії наук було засновано Комітет політичних наук, який став виконувати функцію координатора наукового життя в галузі науки про політику ${ }^{23}$.

Суспільно-політична криза 1980-1982 рр. зумовила посилення уваги до викладання суспільно-політичних знань. У вересні 1985 р. замість курсу «Основи політичних наук» наказом міністра науки та вищої освіти в навчальний процес був впроваджений курс «Наука про політику» (Nauka o Polityce), який складався з чотирьох частин: 1) Основи науки про політику; 2) Політична система суспільства, їі структура та функціонування; 3) Головні течії політичної думки в сучасному світі; 4) Зовнішня політика держави та міжнародні відносини. Був виданий академічний підручник «Наука про політику» під редакцією професора Артура Боднара ${ }^{24}$.

\section{Важкі пологи угорської політології}

Початок процесу становлення політології в Угорщині також був зумовлений спробами реформування соціалістичних відносин, що почалися після придушення антикомуністичного народного повстання 1956 р. Нове партійно-державне керівництво Угорщині на чолі 3 Яношем Кадаром (який в період 1951-1956 рр. також був ув'язнений попереднім режимом Матяша Ракоші) розуміло, що для угамування народного незадоволення комуністичним режимом необхідно вдатися до реформ. Реформи в Угорщині проводилися дуже повільно й зайняли три десятиліття, що було зумовлено боротьбою між реформаторами та консерваторами всередині комуністичного керівництва. 1957 року в Угорщині почалася реформа сільського господарства, внаслідок чого сільськогосподарські кооперативи одержали повну господарську самостійність та власність на землю. У 1968 р. економічні реформи поширилися й на промисловість. Усі промислові підприємства були поділені на три групи: енергетичні та обороні підприємства залишилися під урядовим управлінням; на більшості інших були створені робітничі ради, які разом з адміністрацією стали здійснювати їх управління; дрібні підприємства, на яких працювало менше ста робітників, були перетворені на виробничі кооперативи, що стали управлятися зборами трудового колективу. Одночасно були вжиті заходи з реформування в сфері політичних відносин. На зламі 1966-1967 рр. були ухвалені закони про вибори до Державних зборів та місцевих рад, які передбачали можливість висування на одне депутатське місце декілька кандидатів. Відповідно до нових законів, у березні 1967-го відбулися перші в комуністичному світі вибори в елементами конкурентності. 
Децентралізація економіки, нові відносини в сфері власності на засоби виробництва, посилення соціальної диференціації та кроки в напрямі демократизації кинули виклик існуючий парадигмі політичної системи, що спричинило наприкінці 1960-х рр. початок дискусії про інституційні рамки політичних студій. У ході дискусії зіткнулися дві протилежні точки зору. Одні учасники виступили за інституціоналізацію політології як самостійної наукової дисципліни, що мало сприяти подальшої демократизації країни. Інші вважали, що політичні дослідження, як і раніше, повинні здійснюватися в межах традиційних марксистсько-ленінських дисциплін, аргументуючи неприйняття політології тим, що вона $\epsilon$ буржуазною лженаукою, заснованою на американських гіпотезах, котрі несумісні з марксистськими цінностями ${ }^{25}$. Ця дискусія тривала більше десятиліття й закінчилася перемогою прихильників інституціоналізації політології.

У 1980 р. Угорська академія наук (УАН) заснувала комісію з політології, а потім й наукову комісію для присудження наукового ступеню кандидата політичних наук ${ }^{26}$. У 1982 р. створюється Угорська асоціація політичної науки (Magyar Politikatudományi Társaság) «як форум для реформістські налаштованих комуністів та суспільствознавців, котрі свої наукові інтереси пов'язували 3 політикою, а також для деяких неофіційних мислителів» ${ }^{27}$, що об’єднала в своїх лавах біля 500 науковців та практиків ${ }^{28}$. До 1989 року Угорська асоціація політичної науки була єдиним центром національної та міжнародної співпраці серед орієнтованих на політичну науку суспільствознавців ${ }^{29} .31983$ р. став видаватися «Щорічник Угорської асоціації політичної науки» (А Magyar Politikatudományi Társaság évkönyve) ${ }^{30}$. Щорічник видавався до 1992 року. За цей час вийшло 11 томів ${ }^{31}$.

Велику роль у становленні політології в комуністичній Угорщині відіграв Фонд Сороса, який у середині 1980-х спільно з УАН створив наукову мережу, що надало угорським політологам ширші можливості для участі в освітній та дослідницькій діяльності на Заході. У Східній Європі мережа Сороса розпочала свою діяльність саме з Угорщини. Це справило великий вплив на відкриття суспільно-політичної системи та поширення об'єктивних соціальних наук, включаючи й політичну. Програми мережі Сорос-УАН включали стипендії, гранти на конференції, наукове обладнання, витрати на дослідження та літературу для неофіційних та офіційних структур ${ }^{32}$.

Проте завершити процес інституціоналізації політології як самостійної наукової та навчальної дисципліни за комуністичного режиму в Угорщині не вдалося. Мате Сабо зауважує, що в Угорщині до 1989 року політична наука існувала винятково в усних дебатах, головним чином в межах Угорської асоціації політичної науки, результати яких публікувалися в щорічнику УАПН ${ }^{33}$. Хоча в навчальних процес на гуманітарних факультетах деяких університетів були впроваджені політологічні курси, але вони характеризувалися розмитістю структури, розпливчатістю уявлень щодо об'єкту політичних досліджень та предмету викладання ${ }^{34}$. До 1989 року в угорських вишах викладалася переважно так звана соціалістична політична соціологія. Спочатку на основі угорського перекладу посібника $з$ політичної соціології польського соціолога та політолога Єжи Вятра, котрий намагався імплементувати західні категорії в марксистсько-ленінські постулати ${ }^{35}$. У 1987 році був виданий угорський підручник «Політична та правова соціологія» Кальмана Кульчара, в якому автор, використовуючи певну марксистську фразеологію, в основному імпортував концепції західних суспільних наук ${ }^{36}$.

Завершення процесу інституціоналізації політології в Угорщині відбулося після падіння комуністичного режиму. У 1989 році в структурі УАН був створений Інститут політичної науки (MTA - Politika tudományi Intézete). У 1993 році на філологічному факультеті Мішкольського університету почалася фахова спеціалізація студентів 3 політології ${ }^{37}$.

\section{Узагальнення}

У теоретико-методологічному плані східноєвропейська політологія являла собою еклектичну суміш марксистської теорії політики з західною політологією. Протиставляючи себе західній, східноєвропейська політологія позиціонувала себе як марксистська. Але не маючи в межах марксистської парадигми інструментарію для розв'язання нагальних практичних проблем суспільного розвитку, східноєвропейська політологія була вимушена звертатися до теоретико-методологічних надбань Заходу. Проте інтегрувати їх в аутен- 
тичній формі вона не могла, внаслідок ідеократичного характеру комуністичних режимів. Тому західні концепції адаптувалися в східноєвропейській політології з відповідними ідеологічними корективами.

Так, західна концепція політичних режимів, відповідно до якої сучасні політичні режими поділяються на три основні типи: тоталітарний, авторитарний та демократичний, була перетворена в польській науці про політику на концепцію, в межах якої було вирізнено чотири основні типи політичних режимів. Не визнаючи західну теорію тоталітаризму, в якій тоталітарними визнавалися як фашистські режими (правий тоталітаризм), так і комуністичні (лівий тоталітаризм), східноєвропейська політологія до крайнього типу деспотичних режимів віднесла тільки фашистські. Авторитарні режими були подані в тій же трактовці, що й в західній політології. Західні демократії визначалися як ліберальні режими (не зовсім демократичні, оскільки вони є замаскованою формою диктатури буржуазії). Демократичними визнавалися лише комуністичні режими, бо вони являють собою «народну демократію».

Проте, як зауважують Девід Павелл і Пола Шоуп, «спроби використати західну науку для офіційних цілей не можуть приховати той факт, що в тих країнах, де політичній науці було дозволено розвиватися, відбувся різкий розрив з марксистсько-ленінським підходами до політики та було сприйнято багато термінологічних, методологічних та концептуальних елементів західної політичної науки. У таких випадках можна говорити про принципову зміну методу, під час якої стандарти дисципліни заміщають ідеї ідеології при визначенні обгрунтованості дослідницького та наукового аналізу ${ }^{38}$.

Незважаючи на свої недоліки, політологія в країнах Центрально-Східної Свропи стало важливим чинником реформування суспільно-політичних відносин, що в подальшому створило умови для їх швидкої м'якої декомунізації та демократизації.

\section{Вплив на політичний процес}

Становлення політології було щільно пов'язане з процесом реформування комуністичних суспільств. Реформування, з одного боку, вимагало наукових рекомендацій з вдосконалення суспільно-політичних відносин, а з іншого - створювало більш сприятливі умови для проведення об'єктивних політичних досліджень. У свою чергу, рекомендації політичних науковців, що спиралися на результати політологічних досліджень, посилювали позиції реформаторів в середині комуністичних керівництв. У цьому контексті не випадковим здається те, що саме Польща та Угорщина стали тими країнами, яким вдалося перейти від комуністичного тоталітаризму до ліберальної демократії еволюційним шляхом ${ }^{39}$.

Коли у 1988 р. Польщу охопила нова хвиля антиурядових страйків, для мирного виходу з кризової ситуації було прийнято рішення провести «круглий стіл» 3 представниками влади та опозиції, який відбувся 6 лютого - 5 квітня 1989 р. У ньому взяли участь: від влади - представники ПОРП та афілійованих до неї Об'єднаної селянської партії (ОСП) та Демократичної партії (ДП), від опозиції - офіційно заборонене на той час незалежне профспілкове об'єднання «Солідарність», а також, як посередники, представники католицької церкви. Внаслідок роботи «круглого столу» було ухвалено компромісні рішення: 1) легалізація «Солідарності»; 2) запровадження інституту президентства, але пост президента на найближчі шість років резервувався за Войцехом Ярузельським - Першим секретарем ЦК ПОРП; 3) перехід до двопалатного парламенту; 4) проведення напіввільних парламентських виборів, за яких вибори до верхньої палати (Сенату) проходять за мажоритарною системою вільно, вибори до нижньої палати (Сейму), яка набувала право формування уряду, відбуваються за пропорційною системою, але при цьому були встановлені квоти: ПОРП та ії сателіти (ОСП, ДП та низька інших громадських об'єднань) мають посісти 65\% місць; 35\% мандатів дозволялось одержати «Солідарності». Результати парламентських виборів, які відбулися в червні 1989 р., дали неочікувані для комуністичної влади результати. На виборах до Сенату (100 місць) 99 одержали представники «Солідарності» і ще одне - незалежний кандидат. На виборах до Сейму (460 місць) «Солідарність» здобула 161 місце (35\%), ПОРП - 173 (37,6\%) ії сателіти 126 (27,4\%). Проте після виборів ОСП та ДП відмовились від коаліції з ПОРП та уклали коаліцію з «Солідарністю», що спричинило формування в серпні 1989 р. першого на 
колишньому комуністичному просторі некомуністичного уряду Тадеуша Мазовецького, котрий почав процес посткомуністичної трансформації країни, який дуже швидко та успішно завершився ${ }^{40}$.

В Угорщині на початку 1980-х рр. було скасовано політичну цензуру засобів масової інформації, що зумовило появу опозиційних видань: «Співрозмовник» («Beszélő»), «Бюлетень» («Hírmondó»), «Угорська демократія» («Magyar demokráta»). У грудні 1983 р. був ухвалений новий закон про вибори депутатів Державних зборів, який передбачав обрання депутатів як в одномандатних округах, так і за загальнонаціональним списком. Головною особливістю цього закону стало обов'язкове висування в 352 одномандатних округах на одне депутатське місце не менш як двох кандидатів, що робило політичні вибори певною мірою (наскільки це було можливим в умовах однопартійної системи) конкурентними та альтернативними. Інші 35 депутатів обиралися за одним єдиним списком, який складався 3 партійних та державних діячів, дещо розбавленим представниками науки, культури та церкви. На виборах за новим законом, що відбулися в липні 1985 р., кандидати від Угорській соціалістичній робітничій партії (УСРП) отримали 288 місць 3 387, проте до Державних зборів було обрано й декілька опозиційно налаштованих депутатів. Демократизація політичного життя вплинула й на саму УСРП, в якій все більшої сили набували реформатори. Після відставки у травні 1988 року Яноша Кадара нове партійно-державне керівництво провело в червні - вересні 1989 року серію круглих столів з опозицією, на яких було домовлено про демократизацію країни, включаючи зміну конституції, запровадження багатопартійної системи та проведення вільних парламентських виборів. Під впливом цих рішень УСРП у жовтні 1989 року на своєму XIV з'їзді відмовилася від ідеології марксизму-ленінізму, перейшла на позиції соціал-демократії та змінила свою назву на Угорську соціалістичну партію. На перших вільних парламентських виборах, що відбулися 25 березня та 8 квітня 1990 року, перемогу здобули опозиційні сили, які сформували коаліційний уряд ${ }^{41}$.

Польща та Угорщина стали країнами, які у 1990 році першими на посткомуністичному просторі були визнані вільними та демократичними ${ }^{42}$. Звісно, рівень політологічної думки був лише одним із чинників, що відіграли свою роль на початковій стадї суспільно-політичних трансформацій. Разом з Польщею і Угорщиною в 1990 році була визнана вільною та демократичною й Чехо-Словаччина, але тут відіграло провідну роль масариківська демократична традиція, що знайшла своє втілення у Першій Чехословацькій Республіці 1918-1938 рр., та досвід «Празької весни» 1968 року.

Югославії перейти до демократії еволюційним шляхом, як то сталося в Польщі та Угорщині, не вдалося. Хоча там теж відбувався процес поступової детоталітаризації суспільних відносин та лібералізації політичної системи, але загибель комуністичного режиму відбулась внаслідок розпаду СФРЮ. Міжетнічні конфлікти, пов’язані з розпадом багатонаціональної держави, зумовлені історичними чинниками та шовіністським характером сербського режиму Слободана Мілошевича, завадили еволюційному переходу до демократії постюгославських країн. Низка нових балканських конфліктів суттєво загальмувала демократичний процес. Проте Словенії, яку війна зачепила значно менше за інші постюгославські держави ${ }^{43}$, також вдалося досить плавно подолати наслідки функціонування комуністичного режиму та швидко перейти до ліберальної демократії ${ }^{44}$. У 1991 році Словенія була визнана вільною демократичною державою. У березні 2003 року вона першою $з$ постюгославських країн була прийнята до НАТО, а 1 квітня 2004 року стала членом Європейського Союзу.

\section{Висновки}

Становлення політології в низці країн Центрально-Східної Європи за комуністичних режимів було зумовлене намаганням їх партійно-державних керівництв відійти від сталінської моделі соціалізму, побудувати відносно демократичний соціалізм 3 елементами самоврядування та урахуванням національної специфіки. Реалізація цього завдання вимагала створення структур, які були б у змозі розробити наукові рекомендації щодо реформування суспільно-політичних систем, хоч і в межах соціалістичної парадигми. Саме такими структурами стали політологічні інститути та асоціації. 
Хоча східноєвропейська політологія являла собою еклектичну суміш марксистської теорії політики та західної політології, але ії̈ інституціоналізація зумовила переорієнтацію соціальних студій на реальні проблеми суспільно-політичного розвитку. Через політологію у комуністичні країни просякали західні політичні теорії та концепції, які адаптувалися з урахуванням можливостей, що надавили науковцям політичні режими. Становлення політології також сприяло поверненню до наукового обігу політичних ідей, що були напрацьовані в національних науках у докомуністичний період. У межах східноєвропейської політології постійно виникали дисидентські напрями, які сприяли поступовому випаровуванню марксистських догм 3 політичної науки.

Наукові напрацювання політологів відіграли свою роль в просуванні економічних $\mathrm{i}$ політичних реформ, які підточували тоталітарну систему, та в подальшому сприяли еволюційному переходу до демократії Польщі, Угорщини та, в певному сенсі, Словенії. Після демонтажу комуністичних режимів політична наука східноєвропейських країн, остаточно звільнившись від панування марксистських догм та компартійного впливу, увійшла в річище загальносвітового наукового розвитку.

${ }^{1}$ Романюк О. Політична наука США // Політологічний енциклопедичний словник / за ред. М. П. Требіна. Харків: Право, 2015. С. 561.

${ }^{2}$ Романюк O. I. Від тоталітаризму до демократії та національної державності : системний аналіз посткомуністичних трансформацій: монографія. Харків: ХДАК, 2011. С. 78-80.

${ }^{3}$ У вищій школі НДР читався нормативний курс «Науковий соціалізм, основи вчення історії робітничого руху» («Wissenschaftlicher Socialismus, Grundlehren der Geschichte der Arbeiterbewegung»).

${ }^{4}$ Джорджевич Й. Развитие политических наук в Югославии // Политические науки и НТР: ежегодник САПН. М.: Наука, 1987. С. 227-234.

${ }^{5}$ Jantol T. Povodom 30 godišnjice Fakulteta političkih znanosti u Zagrebu // Politička misao - časopis za političke znanosti. God. XXIX. 1992. No 4. S. 130-135.

${ }^{6}$ Kasapović M. Political Science in Croatia 1962-2007 // European Political Science. Vol. 7. 2008. No 2. P. 237-246.

${ }^{7}$ Мойсевич Ч. Польское объединение политических наук: основные направления деятельности // Политические науки и НТР: ежегодник САПН. М.: Наука, 1987. С. 234-241; Mojsiewicz Cz. Rozmowy o polskiej politologii. Toruń: Wydaw. Adam Marszałek, 2005. 124 s.; Mojsiewicz Cz. Od polityki do politologii. Toruń: Wydaw. Adam Marszałek, 2005. 507 s.

${ }^{8}$ Janowski K. B. Politologii polskiej meandry // Przegląd Politologiczny: Czasopiśme Uniwersytetu im. Adama Mickiewicza w Poznaniu. 2011. № 1. S. 7-23.

${ }^{9}$ Сабослаи Д. Политика как предмет науки в Венгрии // Политические институты и обновление общества: Ежегодник САПН. М.: Наука, 1989. С. 97-102.

${ }^{10}$ Szabo M. Political Science - Hungary // Three social science disciplines in Central and Eastern Europe: handbook on economics, political science and sociology (1989-2001) / Ed by M. Kaase, V. Sparschuh, A. Wenninger. Berlin: GESIS, 2002. PP. 258-274.

${ }^{11}$ Powell D. E., Shoup P. The Emergence of Political Science in Communist Countries // The American Political Science Review. Vol. 64. 1970. No 2. PP. 572-588.

${ }_{12}$ Маркс К. Инструкция делегатам временного Центрального Совета по отдельным вопросам // Маркс К., Энгельс Ф. Соч., 2-е изд. Т. 16. С. 199.

${ }^{13}$ Bilandžić D. Borba za samoupravni socijalizam u Jugoslaviji 1945. Zagreb: IHRPH 1969. $146 \mathrm{~s}$.

${ }^{14}$ Историја удружења за политицке науке Сербије. URL: http://www.upns.rs/node/6 (дата звернення: 8.10.2017).

${ }^{15}$ Jantol T. Povodom 30 godišnjice Fakulteta političkih znanosti u Zagrebu. S. 130.

${ }^{16}$ Kasapović M. Political Science in Croatia 1962-2007.

${ }^{17}$ Mojsiewicz Cz. Rozmowy o polskiej politologii. S. 36.

${ }^{18}$ Mojsiewicz $C z$. Od polityki do politologii. S. 284.

${ }_{19}$ Podstawy marksyzmu-leninizmu: podręcznik / R. Hekker, H. Szpakowicz, M. Michlewicz i inni (tlum.). Książka i Wiedza, 1960. 1032 s.

${ }^{20}$ Janowski K. B. Ta praca. S. 7.

${ }^{21}$ Chodubski A. J. Wstęp do badań politologicznych. Gdańsk: Wydawnictwo uniwersytetu gdańskiego, 2004. S. 43.

${ }^{22}$ Politologia. URL: https://pl.wikipedia.org/wiki/Politologia.

${ }^{23}$ Komitet Nauk Politycznych PAN. URL: https://pl.wikipedia.org/wiki/Komitet_Nauk_Politycznych_ PAN (дата звернення: 18.09.2017).

${ }^{24}$ Nauka o polityce: podrecznyk akademicki / Pod red. A. Bodnara. Warszawa: Państwowe Wydawnictwo Naukowe, 1988. $551 \mathrm{~s}$. 
${ }^{25}$ Сабослаи Д. Политика как предмет науки в Венгрии. С. 98.

${ }^{26}$ Там же. С. 98 п.

${ }^{27}$ Szabo M. Political Science - Hungary. PP. 267-268.

${ }^{28}$ Сабослаи Д. Политика как предмет науки в Венгрии. С. 98п.

${ }^{29}$ Szabo M. Political Science - Hungary. P. 268.

${ }^{30}$ A Magyar Politikatudományi Társaság évkönyve 1983. Politika és társad. URL: http://konyvletoltes.com/Zdj5K_a-magyar-politikatudom $\% \mathrm{C} 3 \% \mathrm{~A} 1$ nyi-t $\% \mathrm{C} 3 \% \mathrm{~A} 1 \mathrm{rsas} \% \mathrm{C} 3 \% \mathrm{~A} 1 \mathrm{~g}-\% \mathrm{C} 3 \% \mathrm{~A} 9 \mathrm{vk} \% \mathrm{C} 3 \%$ B6nyve-1983.htm (дата звернення: 05.08.2017).

${ }^{31}$ Szabo M. Political Science - Hungary. P. 267.

${ }^{32}$ Ibid. P. 260.

${ }^{33}$ Ibid. P. 267.

${ }^{34}$ Сабослаи Д. Политика как предмет науки в Венгрии. С. 98.

${ }^{35}$ Szabo M. Political Science - Hungary. P. 269.

${ }^{36}$ Kulcsar K. Politikai es jogszociologia. Budapest: Kossuth, 1987. 579 old.

${ }^{37}$ Ibid. P. 265.

${ }^{38}$ Powell D. E., Shoup P. The Emergence of Political Science in Communist Countries. P. 572.

${ }^{39}$ Романюк О. I. Від тоталітаризму до демократії та національної державності... С. 245.

${ }^{40}$ Codogni P. Wybory czerwcowe 1989 roku. U progu przemiany ustrojowej. Warszawa: Instytut Pamięci Narodowej, 2012. $360 \mathrm{~s}$.

${ }^{41}$ The Roundtable Talks of 1989: The Genesis of Hungarian Democracy. Analisis and Documents / Ed.by A. Bozóki. Budapest: Central European University Press, 2002. 431 p.

${ }^{42}$ Country and Territory Ratings and Statuses, 1973-2018 (Excel). URL: https://freedomhouse.org/ content/freedom-world-data-and-resources (дата звернення: 25.05.2018).

${ }^{43}$ У процесі розпаду СФРЮ Словенія зазнала «десятиденної війни», яка тривала 327 червня по 7 липня 1991 року і була спричинена спробою Югославської Народної Армії завадити реалізації рішення про державну незалежність Словенії. Війна завершилась підписанням Бріонської угоди, згідно з якою ЮНА припинила бойові дії на території Словенії.

${ }^{44}$ Zajc D. Political Transition and Democracy in Slovenia // Croatian International Relations Review. 2000. Vol. 6. No. 20/21. PP. 127-134; Country and Territory Ratings and Statuses, 1973-2018 (Excel). 